UDC 378.014.242

DOI: $10.52534 / \mathrm{msu}-\mathrm{pp} .7(2) .2021 .54-62$

Lucas Ortega-Abente, Julia Ruiz-Flores ${ }^{*}$

Universidad de Cantabria

39005, Avda. de los Castros, s/n, Santander, Cantabria, Spain

\title{
Psychological Aspects as the Components of Academic Mobility of Medical Workers
}

\section{Article's History:}

Received: 20.12 .2020

Revised: 24.02 .2021

Accepted: 26.04.2021

\section{Suggested Citation:}

Ortega-Abente, L., \& Ruiz-Flores, J. (2021).

Psychological aspects as the components of academic mobility of medical workers. Scientific Bulletin of Mukachevo State University. Series "Pedagogy and Psychology", 7(2), 54-62.

\begin{abstract}
The relevance of the study is conditioned by the need for mastery of "professional mobility" and "reflection" by health professionals in terms of active scientific and technological development and rapid changes in the socio-cultural space. The purpose of the study is to determine the professional mobility of a specialist in the context of the peculiarities of the professional activity of a nurse and to create a methodology for its research. In the course of the study, methods of statistical and mathematical analysis, scientific modelling, as well as testing and generalisation of data were used to conduct an empirical experiment, the essence of which was to create and substantiate the method "Professional mobility of a nurse". The necessity of the professional mobility development of employees of medical institutions is substantiated. The key components of the study of professional mobility of nurses have been established. A method for studying professional mobility and reflection of healthcare workers in the form of a questionnaire "Professional mobility of nurses" has been developed. Statistical processing of the received data has been conducted and the statistical matrix of the specified technique is created. A sample normative scale for the questionnaire has been formed. The reliability of the questionnaire was determined due to the use of the Cronbach's alpha index. The coefficient of discrimination of the method "Professional mobility of nurses" was found. Prospects for further research are seen in the regular use of the developed questionnaire "Professional mobility of nurses" among healthcare workers to actively implement and develop professional mobility to ensure proper socioeconomic stability
\end{abstract}

Keywords: mobility, medicine, worker, academism, structure

\section{INTRODUCTION}

The modernisation of the healthcare system, which primarily involves improving the quality of care for the population, requires a high level of professionalism of medical personnel, competent performance of professional manipulations, practical knowledge of modern technologies, the ability to develop professionalism throughout their working career [1]. The professional and personal development of a medical specialist is determined by the level of development of his professionally important traits, qualities, and abilities. This is a development that includes two interconnected parallel processes:

- professional and personal development of a specialist by a system of advanced training;

- personal and professional self-development, which is the formation of professional mobility, is determined by the ability to make independent and non-standard decisions aimed at increasing the level of their professionalism, the ability to quickly master a new professional and social environment.

In the psychological dictionary, the concept of professional mobility is considered through the term "professional development". Notably that professionalisation, or "professional development", is defined as an integral continuous process of a professional's personality development, starting from the moment of choosing a profession, which lasts throughout the entire professional life of a person and ends when a person stops his professional activity. An important process of professionalisation can be considered the formation of a professional, the development of professionally important qualities, the transition 
of a person to the next level of professionalism [2]. At the stage of professionalisation, the professional development of an individual begins to dominate over the personal and determine it, while during the academic study the ratio of personal and professional development acquires the character of dynamic unbalanced integrity [3]. Moreover, the ability for professional mobility is largely determined by the level of professional development of the individual. Professional development is often viewed as an integration of two processes: personality development in ontogenesis and personality professionalisation from the beginning of professional self-identification to the end of active work activity [4].

Speaking about career models, it is noted that today the importance of such a feature of a career as mobility is increasing, when not only jobs are changing, but also the professions themselves [5]. The professional mobility of a specialist, including a medical worker, includes three following components: professional competence, readiness for change, and personality activity [6]. Professional mobility is social in nature because it is applied only in social systems, and its success depends on the social environment where the personality of a professional specialist develops. Exploring the characteristic features of a specialist's mobility and noting that it is based on the activity of a conscious personality, it should be noted that many scientists, studying professional activity, believe that it is an indicator of the degree of individual's socialisation and is manifested not only in the adaptation of a personality to other professional conditions but also is aimed at changing them [7].

One of the tasks of modern scientific research is the development of a personnel policy in medicine, designed for the development of human resources as a long-term mobile process, full development of the personality when a career reflects the personal development of a professional specialist. In medicine, there should be not only the provision of assistance to the population but also the effective development of personnel. This process is very complex and contradictory, often accompanied by the loss of the previously formed part of human resources, while reproduction does not provide the necessary quantitative and qualitative characteristics of performance potential [8].

Consequently, some grounds make it possible to talk about the socially professional formation and development of a medical specialist, namely about the development of a professionally mobile type of personality. Therefore, the purpose of the study is to determine the professional mobility of a specialist in the context of the characteristics of the professional activity of nurses and to create a methodology for its research. To achieve the purpose, the following objectives were attained during the study:

1. Verification of the proposed theoretical approach to the definition of professional mobility of nurses.

2. Selection of methodological tools to provide the diagnostics of multifaceted psychological aspects of the personality and professional activities of nurses.

\section{MATERIALS AND METHODS}

To conduct an empirical study of the professional mobility of medical workers, the following components were highlighted:

1. Motivational component, which includes a system of motives, goals, needs for self-development, self-improvement, self-education, value system for self-actualisation in professional activity, the need to master effective ways of organising it, to improve professional education, the desire for effective career growth. It contributes to the development of interest in professional activity, to the acquisition of professionally significant knowledge, and creates psychological conditions that encourage a person to perform productive and creative duties and professional functions in the process of activity, to change the types or areas of activity in a dynamic professional space. The main determinant of the motivational component of the professional mobility of nurses is a humanistic worldview, innovation, focus on professional self-development and self-improvement.

2. The adaptive component, highlighted since the changes that occur in the modern world are characterised by continuity and unevenness and often negatively affect the professional activity of an individual. This determines the division of people into those who are highly resistant to change, but do not tend to adapt; those who are unable to adapt and cannot resist change; those who are capable of adaptation and change, but the speed of their adaptive processes is not sufficient; and those who are able to adapt and change quickly, are capable of quick learning, selflearning. This necessitates the development of specialists' resistance to changes and the ability to adapt based on selfstudy and training.

3. The communicative-empathic component includes the concept of the goal, motives, means, and stimuli of communication and empathy, the ability to clearly express thoughts, argue, convey information, organise and maintain a dialogue, use verbal and non-verbal means of transmitting the information. The communicative-empathic component characterises the ability of a professionally mobile specialist to realise the interaction between colleagues and patients, it presupposes the ability to provide support, constructively resolve a conflict situation. In the context of studying the professional mobility and readiness of nurses for professional communication, the communicative-empathic component reflects: the nurse's awareness of the complexity and versatility of professional communicative interaction; knowledge of the theory and technologies of effective interpersonal communication and empathy with different patients (according to gender, age, cultural characteristics, religious worldview) and the ability to analyse dialogical relationships with patients; a complex of knowledge about interpersonal tolerance and the limits of its admissibility, human rights, various mental states of the individual.

4. The organisational component ensures consistency in the professional activity of a nurse, which makes it possible to predict the results of work, organise the implementation 
of decisions, and correct interaction with patients and colleagues. This component includes the ability to organise, structure, rationalise professional activities in the professional sphere, the ability to analyse, design, and predict the results and consequences of actions aimed at solving specific professional tasks and achieving the goals of the professional plan; the ability to organise the activities of the team and patients in the department; the ability to critically evaluate the options proposed by management and substantiate suggestions for their improvement, taking into account performance criteria and possible consequences at nursing conferences. It provides for practicality (the ability to directly, quickly, and flexibly apply one's knowledge and experience in solving practical problems), observation, self-control, sociability, perseverance, activity, efficiency, organisation.

5. The cognitive and competency-based component involves the actualisation of cognitive processes in professional activity - perception, memory, attention, thinking, imagination, the ability to explore, systematically describe, and explain the problemsaspecialistfacesfrom thestandpoint of modern science, ensures the use of modern knowledge for the effective development and implementation of the creative potential of a specialist in professional activities. This component includes professional literacy, professional skills and experience, life experience. The importance of the cognitive and competency-based component for the development of professional mobility of a nurse arises from the level of professional training, emotional and value-based perception of the essence of professional activity in nursing. The cognitive and competency-based component combines the body of knowledge of nurses about the essence and specifics of work. The completeness of this component is the result of the active professional activity of specialists. It is characterised by the volume of knowledge (width, depth, consistency), thinking style, theoretical competencies to perform certain practical professional actions, the development of the necessary skills and abilities for the work of a nurse. Under the cognitive and competency-based component of the professional mobility of nurses, the authors of this study consider the combination of knowledge and skills that reveal the essence and specifics of professional activity and concern the main components of the professional activity of nurses to work in their specialisation.

Based on these components, an empirical study was conducted, the essence of which was to adapt the author's methodology "Professional mobility of a nurse" and check its validity, reliability and appropriateness of use. The experiment involved nurses from the intensive care, cardiology, neurology, and urgent surgery units. The total selection of the empirical study consisted of 140 people aged 20 to 52 who took part in the pilot and main studies, 50 of which were participants in the test study of the pilot stage. The representative selection was constructed in such a way as to reflect the professional activities of nurses in stressful conditions since it is among this contingent of nurses that it is advisable to diagnose the phenomenon of professional mobility. When forming the selection, the requirements for its content were met by choosing a selection, which corresponds to the subject of the study. The nurses studied showed a willingness to cooperate. It should be noted that there is a high level of motivation for introspection.

The study was conducted during 2016-2019 and consisted of the pilot and the main stage. At the first stage of the research, based on a preliminary acquaintance with the problem and the results of its preliminary study, the main attention was focused on choosing the direction of research, developing purposes and objectives, determining the object, subject, and research methods, and choosing possible sources of information. During the main stage, to determine the content of the structure of professional mobility of nurses, instructions for respondents were developed and clarified, an empirical research programme, which covers the methods, the studied components, and components of professional mobility was developed. At the final stage of the study, a mathematical and statistical analysis of the obtained empirical data, their structuring, generalisation, and systematisation was carried out; the data obtained during the empirical study were processed according to standard programmes of mathematical statistics. After the diagnostic testing, the output results were calculated, based on which the representatives of the studied contingent of nurses were analysed. Based on the primary processing of the results of the psychological examination of nurses, analytical tables and data matrices were compiled. The obtained data were further subjected to statistical analysis methods. Statistical processing of the obtained data was carried out using the nonparametric Pearson $\chi^{2}$ test to identify statistically significant differences in the distribution of indicators for determining professional mobility in a selection of nurses working in a stressful hospital environment; Student's t-test for checking statistical differences in method indicators (significance level $\mathrm{p} \leq 0.05$ ); factor analysis to identify latent variable factors responsible for the presence of correlations between the studied phenomena and cluster analysis to divide a set of objects into homogeneous groups (clusters) according to certain formal criteria of similarity. For mathematical and statistical processing at the primary and secondary levels, specialised software packages for statistical calculations were used, such as Microsoft Office Excel 2019, SPSS, which ensured the implementation of generally accepted univariate statistics and multivariate mathematical statistical methods. Subsequently, a psychological interpretation of the results was realised, conclusions were drawn about the informativeness of the chosen approach to the study of the reflexive mechanisms of professional mobility of nurses, and prospects for further studies of this kind were outlined.

The programme for studying the professional mobility of nurses, developed on a systemic integrated basis, the use of a number of methods and psychodiagnostic 
research methods, the clarity of planning and the specification of stages of the study, give the right to assert that the results are likely in the study of the professional mobility of nurses. It should also be mentioned that the given psychodiagnostic techniques have the advantage of having a rather long history of application in the study of professionally important qualities of various categories of specialists, which is convincing evidence of their relevance and reliability.

\section{RESULTS AND DISCUSSION}

Today, the importance of nursing is growing all over the world. A highly qualified nurse must have sufficient knowledge, skills, and confidence to plan, implement, evaluate care, i.e., to be professionally mobile [9]. The importance of the study of professional mobility lies in the fact that there is an active development of the legislative framework in the field of nursing and it is necessary to accelerate the adaptation of the domestic regulatory framework to world standards due to the introduction of medical reform. There is every reason to classify the nursing profession as one of the most mentally stressful. Work in the medical industry involves constant communication with people, and a significant degree of responsibility in caring for patients, carrying out procedures, working with medical supplies, especially if it is work in busy departments of an in-patient hospital with seriously ill patients. Therefore, the logic of investigating the professional mobility of an individual on the example of the study of the professional activity of nurses working in stressful conditions is warranted [10].

Professional mobility as a personality trait of a specialist in the medical field includes the following components: a set of competencies that ensure the professional mobility of a mid-level medical worker, including key competencies: health preservation, social interaction, communication, information technology competence, and general professional competencies: executive, organisational, projective, clinical interaction; readiness to change as a synthesis of resistance and "reactive" adaptation; activity as the ability to transform professional activity and oneself in it [11]. According to this, several important components are distinguished in the concept of "professional mobility of a nurse". The first is connected with the readiness of a nurse for professional activity, which is reflected in the professional competency of a specialist [12]. To be mobile, a nurse must be able to adapt to new conditions: medical, social and medical institutions, government bodies, be able to use innovative technologies and equipment in professional activities - this is determined by their adaptability. A mobile nurse should not only be able to adapt to new conditions, but also be responsible for making certain decisions independently; this reflects responsibility as a personal quality of a specialist. Finally, to be mobile, a nurse needs to constantly improve, self-develop, and realise herself both in her professional activity and the professional team [13].

A medical worker, to psychologically meet the modern requirements of life and profession, must improve intellectually, morally, communicatively, and emotionally. Such improvement is within the power of a person whose personal changes are directed and mediated by psychological means, for example, reflexive mechanisms [14]. In this regard, the study of professional reflection in a healthcare specialist is of particular relevance, because the psychological ways of mastering the medical profession have been studied in less detail compared to other professions. Meanwhile, medical practice is inherently reflective. The high social significance of the activity of a medical worker determines high requirements for his professional level, which also increases attention to the problem of reflection of professional activity because one of the functions of reflection is to ensure a conscious attitude of the subject to the activity [15].

In the modern professional world, a mid-level medical worker needs reflexive skills that have a positive effect on his activities and the activities of the team [16]:

- to draw up and agree on plans for the activities of the team;

- to compose and implement the nursing process;

- to develop and implement a professional self-education programme;

- to analyse professional problems and find ways of their constructive solution;

- to search for ways to achieve the set goals and objectives;

- to implement reflexive management of the nursing staff;

- to conduct self-presentation;

- to carry out emotional and volitional self-regulation.

The study of the reflection of the specialists' professional activity made it possible to single out the unconscious and conscious levels of the professional development of the individual. The unconscious level is characterised by unconsciousness, the indistinctness of the personality's ideas about their own potential capabilities, the dependence of professionalisation on external circumstances and influences, lack of reflection on professional development and personal responsibility for its course and results. A conscious professional attitude is accompanied by formed professional motivation, active and creative actions and deeds, subjective search, and extraction of personal meanings in professional activity, which in general ensures professional maturity [17].

Various approaches to the study of reflection are due to the differences in the views of psychologists in the definition of the term "reflexive mechanisms". Thus, in the mental sphere, two complementary reflexive mechanisms are distinguished: generation and control; in the sphere of consciousness - self-mobilisation and self-organisation; in the field of communication and cooperation - "reflexive immersion in the environment", the attitude towards cooperation, the openness of one's own experience for others and vice versa [18]. Reflexive activity is understood as a condition for self-development, an indicator of personal and professional values and meanings, reflecting the individual experience of studying the content of the professional sphere and a system of methods of introspection, self-prediction, self-control, self-assessment, and freedom of choice of means of achieving results. The main mechanisms of reflexive activity include the mechanism of cognition and the mechanism of development; fixation, problematisation, self-determination, self-esteem, motivation; 
self-knowledge, self-determination, introspection, self-programming. Reflection in the profession should be considered as the focus of reflective thinking on the objects of professional activity, which are the development of professional qualities. According to the personal paradigm, professional reflection is considered as one of the methods of self-knowledge and self-improvement, as an integral component. In the professional activity of a medical worker, reflection is not only a means but also a goal of training, not only a process of self-knowledge but also a content, a source of personal experience, a factor in the actualisation of the development of professional culture [19].

Among the personal qualities and traits that form the ability and readiness for professional mobility of nurses, the following are dominating: initiative; professional activity; ability to take risks; self-organisation, independence, volitional self-control; persistence; the ability to hold feelings and emotions; independence of decision-making in difficult situations; decisiveness in determining the basic issues of life and professional sphere of activity; self-confidence; initiative; resistance to frustrations of the internal and external environment.

Thus, the transformational changes taking place in the state increasingly pose a challenge for scientists not only to develop new approaches in medical practice but also to provide specific proposals. In this case, the combination of the term "reflection" with the term "professional mobility" made it possible not only to make scientific research on a relevant and modern scientific topic but also to propose a strategy, a model for the development of professionalism of personnel in the field of medicine, which is based on the use of systemic and structural methodology, specifically on a fundamentally new structure of professional staff mobility [20].

Based on the theoretical analysis of the professional mobility of nurses, it is worth noting that in modern psychodiagnostics no methodology is aimed at studying this particular phenomenon. Therefore, the problem of creating a psychological toolkit, aimed at a comprehensive examination of the named phenomenon arose, which provides an opportunity to measure the level of professional mobility of a nurse. The essence of the developed methodology consisted in the choice of the studied phenomenon, that is, the phenomenon of professional mobility of nurses working in stressful conditions, the definition of this methodology as a subjective type of tests and the choice of the type of tasks with the proposed answers, the selection of the primary form of tasks by the criterion-key principle, assessment of tasks of a primary test form, conducting preliminary testing, developing an empirical data form, determining the validity, reliability, and discrimination of the test, as well as standardising the questionnaire. The methodology consists of 15 questions and determines the level of development of professional mobility among nurses.

Before the study, the questionnaire passed an expert assessment on the following indicators:

- compliance with the concept (corresponds, partially corresponds, does not correspond);

- unambiguity of formulation of questions (unambiguous, not entirely unambiguous, not unambiguous);

- suitability of answer options (suitable, partially suitable, not suitable).

Qualified specialists with high professional qualities, including the availability of special training, competence, and work experience, were involved as experts. As a result of the expert assessment in the secondary version of the methodology, the content of some questions was improved and the answers to the questions were built on a Likert scale (from -2 to +2 ). The selection of standardisation of the methodology "Professional mobility of a nurse" was 140 people $(\mathrm{N}=140), 50$ of which became respondents to the test study after 20 weeks.

Each participant of the study was supposed to have a specific instruction: "Please rate Your expressions of the signs of professional mobility of a nurse by checking the box next to the appropriate option, on a scale from -2 to 2, where:

- -2 - the sign is not expressed;

- -1 - more not expressed than expressed;

- 0 - difficult to assess;

- 1 - more expressed than not expressed;

- 2 - the sign is expressed".

Statistical processing carried out using the statistical packages Statistica 6.0 and SPSS for Windows made it possible to formulate the results, which were later displayed in the statistical matrix of the methodology (Table 1).

Table 1. Statistical matrix of the methodology "Professional mobility of a nurse"

\begin{tabular}{|c|c|c|c|c|c|c|c|}
\hline & $\mathbf{N}$ & Arithmetic mean & Median & Min & Max & Standard deviation & Dispersion \\
\hline $\begin{array}{c}\text { Level of professional } \\
\text { mobility }\end{array}$ & 140 & 55.54 & 56.5 & 23 & 75 & 9.832 & 96.667 \\
\hline
\end{tabular}

Having received the results of the statistical matrix of the methodology, the authors of the study constructed a sample normative scale for the questionnaire. When divided into three levels of professional mobility, the limit values of the norm for the low-level indicator are 15-34 points, for the average level indicator - 35-54 points, for the high-level indicator - 55 points or more. To check the normality of distribution, a visual assessment of the histogram was used. The results are shown in Figure 1. 


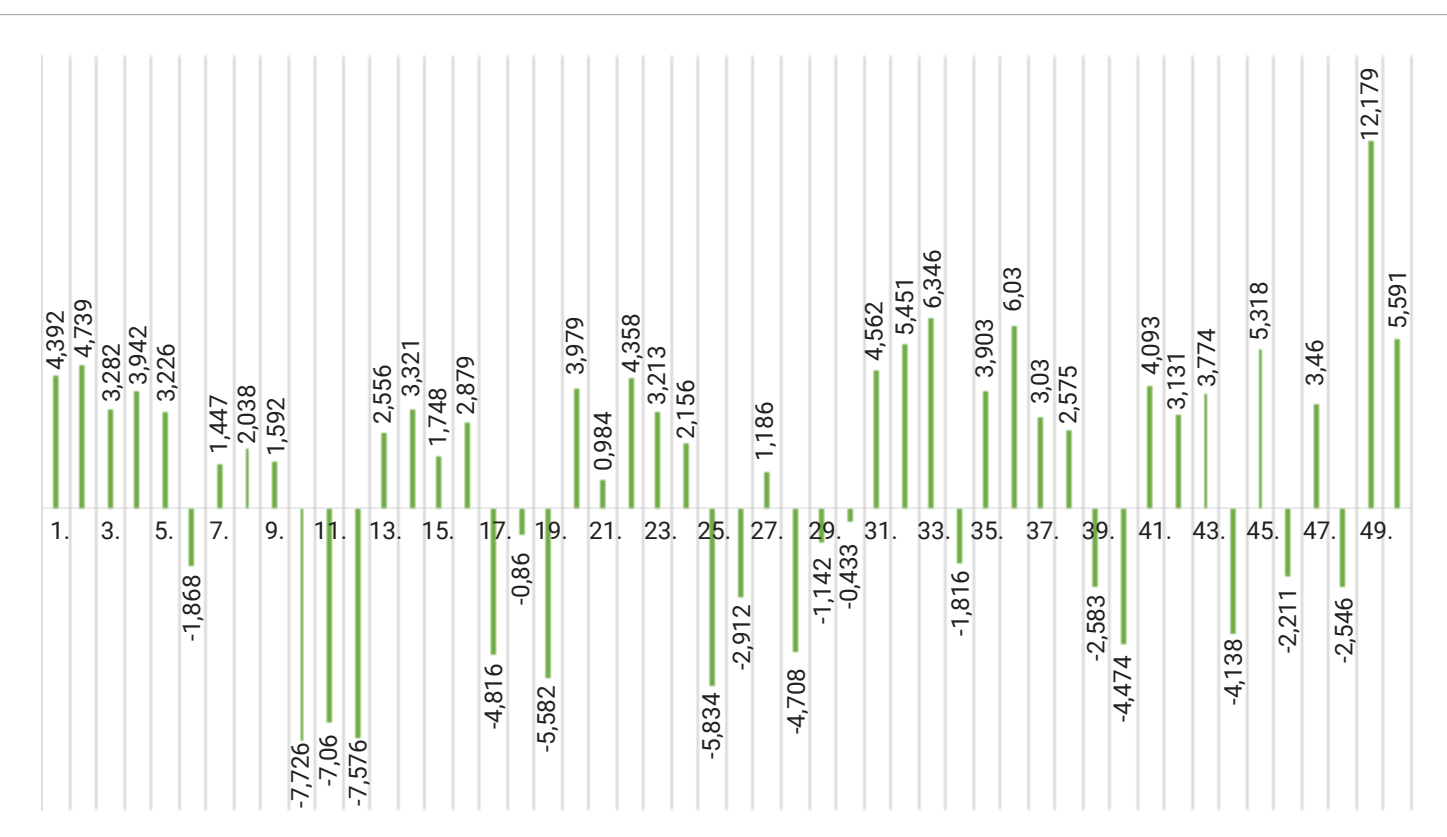

Figure 1. Normal distribution of data according to the methodology "Professional mobility of a nurse"

Speaking about the optimal complexity of problems, it is necessary to point out that the difficulty of test items is such a characteristic, that reflects its statistical level of possibility of solving. Testing the complexity of the questions showed that this test consists of problems with the optimal level of difficulty. This is evidenced by the fact that all the surveyed nurses scored at least $50 \%$ of the maximum possible number of points. In the process of adapting the methodology, it was found that all the subjects cope with each of the tasks, so all 15 questions were recognised as successful and left in the test.

Test reliability is a means of determining the reliability of a psychodiagnostic methodology, in which indicators of the accuracy and stability of the results are determined by repeated research. Reliability, in this case, is established as a measure of the coincidence of the results of the first and repeated surveys, or as the degree of preservation of rank places surveyed in the test sample. The coefficient of reliability $r$ is equal to the coefficient of correlation between the data of such surveys. If a quantitative interval scale is used to measure the psychological property in the test under study, then the Pearson correlation coefficient can be used in determining the results.

The test reliability of the methodology was determined by the repeated questionnaire of the subjects 20 weeks after the first questionnaire. Retesting was conducted for a selection of 50 people. The correlation between the results of the first and second tests was at the level of $r=0.8665$, which indicates fairly high test reliability of the questionnaire.

The process of determining the reliability of the questionnaire consisted of several stages. The first step in processing the resulting raw data was to check the internal consistency of the questionnaire. For this, the statistical Cronbach's alpha index was calculated, which shows the internal consistency of characteristics describing one object. Cronbach's alpha will increase as the cross-correlations of the variables increase; therefore, it is considered a marker of internal consistency in assessing the reliability of test results. Cronbach's alpha indicates the degree to which all items measure the same feature, this coefficient is most appropriate to use when all items are aimed at measuring the same phenomenon. A high coefficient value indicates that the set of questions has a common basis. The value of Cronbach's alpha for the level of professional mobility for 15 questions was $\alpha=0.903$, which is slightly higher than the minimum acceptable value, which is $\alpha=0.7$. Therefore, it can be argued that all items have high differential strength and should not be excluded from the final version of the questionnaire. The results of checking the reliability of the methodology "Professional mobility of a nurse" are presented in Table 2.

Table 2. Statistics of methodology statements "Professional mobility of a nurse"

\begin{tabular}{|c|c|c|c|}
\hline Methodology statement & Average number & Mean standard deviation & $\mathbf{N}$ \\
\hline 12. Psychological comfort & 4.02 & 0.901 & 140 \\
\hline 3. Fast decision-making & 3.93 & 0.964 & 140 \\
\hline 1. Organisation of the working day & 3.84 & 0.972 & 140 \\
\hline 8. Ability to endure heavy physical activity & 3.84 & 0.916 & 140 \\
\hline 2. Self-control & 3.83 & 1.017 & 140 \\
\hline 15. Active participation in conferences & 3.81 & 1.031 & 140 \\
\hline
\end{tabular}


Table 2, Continued

\begin{tabular}{|c|c|c|c|}
\hline Methodology statement & Average number & Mean standard deviation & $\mathbf{N}$ \\
\hline 11. Self-reliance in providing assistance & 3.72 & 0.997 & 140 \\
\hline $\begin{array}{l}\text { 14. Delivering moral and psychological care to } \\
\text { patients }\end{array}$ & 3.68 & 1.020 & 140 \\
\hline $\begin{array}{l}\text { 10. Ability to perform several types of activities } \\
\text { at the same time }\end{array}$ & 3.68 & 0.850 & 140 \\
\hline 9. Ability to stay focused on several patients & 3.64 & 0.975 & 140 \\
\hline 4. Proper care & 3.55 & 1.108 & 140 \\
\hline 6. Manual dexterity & 3.55 & 1.146 & 140 \\
\hline 13. High performance under stressful conditions & 3.54 & 0.940 & 140 \\
\hline 7. Control over the sanitary and hygienic state & 3.54 & 1.020 & 140 \\
\hline 5. Mastering new technologies & 3.38 & 1.190 & 140 \\
\hline
\end{tabular}

The constructive validity of the developed methodology was determined based on correlations with the indicators of the methodology "Diagnostics of the motivational structure of personality" (scales of "general activity", "creative activity"), methodology "style of self-regulation of behaviour-98" (scales of "planning", "flexibility", "independence", "general level of self-regulation"), and a questionnaire of professional self-development (scale "self-government in the profession").

Based on the analysis, it can be concluded that the data obtained provide information on the presence of high positive correlations of professional mobility indicator of a nurse with the following variables: on the scale of "general activity" ( $\mathrm{r}=0.412)$ at $\mathrm{p}<0.000$; on the scale of "creative activity" $(\mathrm{r}=0.354)$ at $\mathrm{p}<0.001$; on the "planning" scale $(\mathrm{r}=$ $0.204)$ at $p<0.006$; with the scale "flexibility" $(r=0.364)$ at $\mathrm{p}<0.001$; on the scale of "independence" $(\mathrm{r}=0.345)$ at $\mathrm{p}<0.002$; with the scale "general level of self-regulation" ( $\mathrm{r}=$ 0.403 ) at $p<0.007$; with a scale of "self-management in the profession" $(\mathrm{r}=0.233)$ at $\mathrm{p}<0.001$.

Additionally, a procedure for checking the discrimination of the questionnaire tasks was carried out, that is, the ability of individual tasks of the methodology to distinguish between subjects with high or low test results, as well as subjects with high productivity of professional activity from those for where it is low, where the main indicator of the coefficient was calculated separately for each statement (Table 3 ).

Table 3. Indicators of the coefficient of discrimination of the methodology "Professional mobility of a nurse"

\begin{tabular}{|c|c|c|}
\hline Methodology statement & Correlation coefficient & $\mathbf{N}$ \\
\hline 8. Ability to endure heavy physical activity & 0,72 & 140 \\
\hline 6. Manual dexterity & 0,70 & 140 \\
\hline 15. Active participation in conferences & 0,67 & 140 \\
\hline 3. Fast decision-making & 0,64 & 140 \\
\hline 4. Proper care & 0,63 & 140 \\
\hline 13. High performance under stressful conditions & 0,60 & 140 \\
\hline 2. Self-control & 0,58 & 140 \\
\hline 14. Delivering moral and psychological care to patients & 0,57 & 140 \\
\hline 5. Mastering new technologies & 0,55 & 140 \\
\hline 7. Control over the sanitary and hygienic state & 0,55 & 140 \\
\hline 1. Organisation of the working day & 0,54 & 140 \\
\hline 10. Ability to perform several types of activities at the same time & 0,53 & 140 \\
\hline 9. Ability to stay focused on several patients & 0,52 & 140 \\
\hline 11. Self-reliance in providing assistance & 0,50 & 140 \\
\hline 12. Psychological comfort & 0,50 & 140 \\
\hline $\begin{array}{l}\text { As can be seen from the results presented in Table the } \\
\text { 3, the correlation coefficients of all test questions indicate } \\
\text { its high discrimination. Consequently, the indicators of } \\
\text { discrimination allow us to say that each specific item on "-2" } \\
\text { the test reliably distributes the subjects with high and low "2" } \\
\text { scores. The final version of the methodology "Professional } \\
\text { mobility of a nurse" consists of } 15 \text { questions and diagnoses the }\end{array}$ & \multicolumn{2}{|c|}{$\begin{array}{l}\text { the level of professional mobility of a nurse. } \\
\text { The standard testing procedure provides four } \\
\text { options for answers, which are rated on the following scale: } \\
\text { "-2" - } 1 \text { point; “-1" - } 2 \text { points; "0" - } 3 \text { points; " } 1 \text { " - } 4 \text { points; } \\
\text { " } 2 \text { " - } 5 \text { points. The maximum score on the methodology is } \\
75 \text { points. The limit values of the norm for the indicator of } \\
\text { the level of professional mobility of a nurse are: }\end{array}$} \\
\hline
\end{tabular}


- low level - 15-34 points;

- average level - 35-54 points;

- high level - 55 points or more.

The low level of professional mobility indicates that it is difficult for these workers to adapt to changes in the professional sphere, they find it difficult to solve professional tasks of a complex level, it is difficult for them to develop and improve themselves. The average level of professional mobility of nurses means that such individuals adapt to various changes in the professional sphere with some difficulties, effectively solve professional problems only of their qualification level, are capable of professional self-development and self-improvement. The high level of professional mobility of nurses allows an individual to quickly adapt to various changes in the professional sphere, unconventionally think and act, effectively solve professional problems of different levels, and be capable of professional self-development and self-improvement.

\section{CONCLUSIONS}

Thus, the professional mobility of nurses is an external manifestation of the internal properties and processes of the personality, aimed at finding a place in the system of professional relations and the successful implementation of the needs in professional advancement. Accordingly, in the structure of professional mobility of nurses, it is expedient to highlight personal and activity components. The personal component of professional mobility determines the qualitative characteristics of a specialist according to the content of professional mobility (motivation, adaptation, and communication), the activity component represents the components of professional mobility, manifesting behavioural structures that are reflected in the professional activity of a professionally mobile specialist (cognition, organisation, competency).

The study examined the professional mobility of specialists in the field of medicine in the unity of the main components such as motivational, adaptive, communicative-empathic, organisational, and cognitive and competency-based. Based on these components, an empirical study was conducted, the essence of which was to create a questionnaire to determine the professional mobility of nurses, thereby the results were obtained and systematised, confirming a sufficiently high level of mobility in healthcare workers.

\section{REFERENCES}

[1] Rumberger, R.W., \& Larson, K.A. (1998). Student mobility and the increased risk of high school dropout. American Journal of Education, 107(1), 1-35.

[2] Song, X., \& McCarthy, G. (2018). Governing Asian international students: The policy and practice of essentialising "critical thinking". Globalisation, Societies and Education, 16(3), 353-365.

[3] Torres, S.M. (2014). The relationship between Latino students' learning styles and their academic performance. Community College Journal of Research and Practice, 38(4), 357-369.

[4] Martinez-Roget, F., Pereira, X., \& Pawlowska, E. (2013). Academic tourism in Galicia: Other form of universities contribution to local economies. Cuadernos de Turismo, 32, 229-242.

[5] Langenkamp, A.G. (2016). Effects of school mobility on adolescent social ties and academic adjustment. Youth and Society, 48(6), 810-833.

[6] Somers, T. (2017). Content and language integrated learning and the inclusion of immigrant minority language students: A research review. International Review of Education, 63(4), 495-520.

[7] Mcdowell, T., Brown, A.L., Cullen, N., \& Duyn, A. (2013). Social class in family therapy education: Experiences of low SES students. Journal of Marital and Family Therapy, 39(1), 72-86.

[8] Sanderson, D.R. (2003). Veteran teachers' perspectives on student mobility. Essays in Education, 4, article number 1.

[9] Medina-Sanchez, G., Torres-Jimenez, E., Romero-Carrillo, P., \& Dorado-Vicente, R. (2014). Teaching technical communication in English to European engineering students. International Journal of Engineering Education, 30(2), 388-399.

[10] Spiegler, T., \& Bednarek, A. (2013). First-generation students: What we ask, what we know and what it means: An international review of the state of research. International Studies in Sociology of Education, 23(4), 318-337.

[11] Kaur, K. (2019). Crossing borders... shifting sands: An investigation of Chinese students' study experiences in the UK and China. Studies in Second Language Learning and Teaching, 9(3), 451-472.

[12] Wu, J., \& Zhang, Y. (2010). Examining potentialities of handheld technology in students' academic attainments. Educational Media International, 47(1), 57-67.

[13] Villar-Onrubia, D., \& Rajpal, B. (2016). Online international learning: Internationalising the curriculum through virtual mobility at Coventry University. Perspectives: Policy and Practice in Higher Education, 20(2-3), 75-82.

[14] Muldoon, O.T., \& Reilly, J. (2003). Career choice in nursing students: Gendered constructs as psychological barriers. Journal of Advanced Nursing, 43(1), 93-100.

[15] Rao, N., Mace, W., Hosein, A., \& Kinchin, I.M. (2019). Pedagogic democracy versus pedagogic supremacy: Migrant academics' perspectives. Teaching in Higher Education, 24(5), 599-612.

[16] Brüggmann, D., \& Groneberg, D.A. (2017). An index to characterize female career promotion in academic medicine. Journal of Occupational Medicine and Toxicology, 12(1), article number 18(2017). doi: 10.1186/s12995-017-0164-7.

[17] Johnstone, C., \& Edwards, P. (2019). Accommodations, accessibility, and culture: Increasing access to study abroad for students with disabilities. Journal of Studies in International Education, 24(4), 424-439. 
o

[18] Rodríguez, X.A., Martínez-Roget, F., \& Pawlowska, E. (2012). Academic tourism demand in Galicia, Spain. Tourism Management, 33(6), 1583-1590.

[19] Orazbayeva, B., Davey, T., Plewa, C., \& Galán-Muros, V. (2019). Engagement of academics in education-driven university-business cooperation: A motivation-based perspective. Studies in Higher Education, 45(8), 1723-1736.

[20] Jin, J., \& Ball, S.J. (2020). Meritocracy, social mobility and a new form of class domination. British Journal of Sociology of Education, 41(1), 64-79.

\title{
Лукас Ортега-Абенте, Джулія Руіс-Флорес
}

Університет Кантабрія

39005, Авеніда де лос Кастрос, б/н, м. Сантандер, Кантабрія, Іспанія

\section{Психологічні аспекти як складові академічної мобільності медичних працівників}

\begin{abstract}
Анотація. Актуальність дослідження визначається необхідністю володіння «професійною мобільністю» та «рефлексією» спеціалістами в сфері охорони здоров'я в умовах активного науково-технічного розвитку та стрімких змін в соціокультурному просторі. Метою роботи є визначення професійної мобільності спеціаліста в контексті особливостей професійної діяльності медичної сестри та створення методики для ії дослідження. У ході дослідження для проведення емпіричного експерименту, суть якого полягала у створенні та обгрунтуванні методики «Професійна мобільність медичної сестри», були використані методи статистичного та математичного аналізу, метод наукового моделювання, а також тестування та узагальнення даних. Обгрунтовано необхідність розвитку професійної мобільності у працівників медичних закладів. Сформовано ключові компоненти дослідження професійної мобільності медичних сестер. Розроблено методику дослідження професійної мобільності та рефлексії працівників сфери охорони здоров’я у вигляді опитувальника «Професійна мобільність медичних сестер». Проведено статистичну обробку отриманих даних та створено статистичну матрицю вказаної методики. Сформована вибіркова нормативна шкала для опитувальника. Визначено надійність використання опитувальника завдяки застосуванню показника альфа Кронбаха. 3’ясовано коефіцієнт дискримінантності методики «Професійна мобільність медичних сестер». Перспективи подальших досліджень вбачаються у регулярному застосуванні розробленого опитувальника «Професійна мобільність медичних сестер» серед працівників сфери медичного обслуговування з метою активного впровадження та розвитку професійної мобільності задля забезпечення належної соціально-економічної стабільності
\end{abstract}

Ключові слова: професійна мобільність, медицина, працівник, структура, опитувальник 